\title{
THE FRACTIONATION OF CHOLESTEROL IN BODY FLUIDS BY MEANS OF SOLVENT EXTRACTION ${ }^{1}$
}

\author{
BY SANFORD O. BYERS AND MEYER FRIEDMAN
}

(From the Harold Brunn Institute, Mount Zion Hospital, San Francisco 15, Calif.)

(Submitted for publication August 19, 1955; accepted December 19, 1955)

In an earlier study (1) it was found that cholesterol absorbed from the intestinal lumen differed from cholesterol secreted into the plasma by the liver in that the former entered and circulated in plasma (for a time at least) enmeshed in a lipid aggregate (i.e., as chylomicra) but the latter entered and circulated in plasma as one of its solutes. It was observed that not only could these two types of cholesterol be separated by physical methods (e.g., by ultracentrifugation) but also that they were handled differently by the body. Thus cholesterol in chylomicron form was deposited in the hepatic reticuloendothelial cell but no such disposition occurred in the case of endogenously produced plasma-soluble cholesterol (2).

Indeed, it has been observed by several investigators (3-5) that treatment of sera with various fat solvents such as an alcohol-ether solution or chloroform leads to an extraction of cholesterol, the degree of which is dependent seemingly upon the increment of cholesterol which remains unbound with protein and apparently is carried in the other lipids of serum. Since a chylomicron consists of various lipids and may contain cholesterol with but little protein, it seems reasonable to believe on a priori grounds, that its cholesterol content might be more easily removed by suitable extracting agents than cholesterol already bound to protein. If such were the case, then analysis of appropriate extracts of a given serum might offer a means of estimating the respective amounts of cholesterol present in lipoprotein form and that present unbound to protein and ostensibly carried in a lipid aggregate.

In the present report, extraction of the intestinal lymph and of the serum of the rat under various conditions has been done. Studies of the rabbit

1 Aided by Grants from the Life Insurance Medical Research Fund, The San Francisco Heart Association and the American Heart Association. also were made. The results suggest that any increase in the amount of "easily extractable" cholesterol obtained from the serum of either the normo- or hypercholesteremic rat is proportionate to an associated increase in the lipid fraction of the same serum sample.

\section{METHODS}

\section{Cholesterol extraction of rat and rabbit sera}

The cholesterol extraction of samples of intestinal lymph and of normocholesteremic and hypercholesteremic serum was performed by one of the techniques of Macheboeuf and Sandor (3) as follows: $1 \mathrm{ml}$. of freshly obtained serum, heparinized plasma, lymph or chylomicron suspension was placed in the bottom of a heavy walled test tube of approximately $10 \mathrm{~mm}$. internal diameter. One ml. of a mixture of 1 volume of absolute ethanol with 9 volumes of ether was layered over the watery fluid, the tube sealed with a paraffin-covered cork and inverted exactly 20 times. The tube was then placed upright at $4^{\circ} \mathrm{C}$. for 20 hours. At the end of this time the upper ether layer was transferred to a suitable container by means of a dropper pipette. One ml. of fresh alcohol-ether (A-E) solution was carefully layered over the serum or other fluid, and immediately removed. This wash was repeated a second time. The combined extract and washings were then analyzed for cholesterol by our usual methods, as was the lower watery layer. A preliminary cholesterol and lipid analysis of each serum or lymph was obtained, the cholesterol analysis by the method of Saifer and Kammerer (6) and the lipid analysis by the method of Bragdon (7).

Fifteen normal male rats of Long Evans strain (av. wt. : 275 grams) were given $100 \mathrm{mg}$. of cholesterol dissolved in $3 \mathrm{ml}$. of olive oil by stomach tube. Blood samples obtained by bleeding ether-anesthetized animals from the tail before and 3, 6 and 12 hours after the feeding were analyzed for cholesterol and then submitted to the extraction procedure. Three unfed control rats were bled at the same time intervals and the samples were similarly treated.

Six normal rabbits (av. wt.: 1609 grams) were given $400 \mathrm{mg}$. of cholesterol dissolved in $12 \mathrm{ml}$. of olive oil by stomach tube. Blood samples were obtained before and at $3,6,12$ and 24 hours after the feeding. A portion was reserved for cholesterol analysis and the remainder submitted to the extraction procedure. 


\section{Cholesterol extraction of rat intestinal lymph}

Three series of normal male rats (Long Evans strain) were used in this experiment. Series I (6 rats) were given $3 \mathrm{ml}$. of $\mathrm{H}_{2} \mathrm{O}$ by stomach tube; Series II (19 rats) were given $3 \mathrm{ml}$. of olive oil by stomach tube; Series III (26 rats) were given $100 \mathrm{mg}$. of cholesterol dissolved in $3 \mathrm{ml}$. of olive oil. The intestinal lymph of the rats of all three series was collected for 24 hours by previously described methods (1) and a sample of each lymph was analyzed for cholesterol and then submitted to the extraction procedure.

\section{Cholesterol extraction of rat hypercholesteremic sera}

A. Triton induced hypercholesteremia (rat): Ten male rats of Long Evans strain (av. wt.: 291 grams) were injected intravenously with $100 \mathrm{mg}$. of Triton WR-1339 after a fasting period of 20 hours and blood samples obtained before and 6 and 24 hours after injection were analyzed for cholesterol and lipid and then submitted to the extraction procedure.

B. Cholate induced hypercholesteremia (rat): Twelve male rats of Long Evans strain (av. wt.: 280 grams) were submitted to biliary obstruction which induced hypercholesteremia by elevation of the plasma cholate concentration (8). Blood samples obtained before and 6 and 24 hours after biliary obstruction were analyzed for cholesterol and lipid and then submitted to the extraction procedure.
RESULTS

A. The cholesterol extraction of rat and rabbit sera before and after oral ingestion of cholesterol

When the sera of 15 normal rats which had been fasted for 18 hours was submitted to the extraction procedure with A-E solution, little of its cholesterol was removed. As Table I demonstrates, the average cholesterol concentration of the A-E solution was only $1.4 \mathrm{mg}$. per $100 \mathrm{ml}$. or about 3 per cent of the total plasma cholesterol concentration (61 mg. per $100 \mathrm{ml}$.). However, when the sera of the same rats were again submitted to extraction three hours after the oral ingestion of 100 $\mathrm{mg}$. of cholesterol in $3 \mathrm{ml}$. of olive oil, the amount of extracted cholesterol more than tripled (see Table I) and equalled 8 per cent of the initial total plasma cholesterol concentration. These sera also exhibited turbidity and chylomicra. Although extraction of similarly turbid sera obtained six hours after feeding gave a value almost the same ( $5.8 \mathrm{mg}$. per $100 \mathrm{ml}$.) as that obtained after three hours, a considerably greater fraction of

TABLE I

The cholesterol extraction of serum of the cholesterol fed rat and rabbit

\begin{tabular}{|c|c|c|c|c|c|c|}
\hline & \multicolumn{6}{|c|}{ Cholesterol (mg./100 ml.) } \\
\hline & \multicolumn{3}{|c|}{ Rats (15) Av. wt. $=303$ grams } & \multicolumn{3}{|c|}{ Rabbits (6) Av. wt. $=1,609$ grams } \\
\hline & Av. & Range & S.E. mean & Av. & Range & S.E. mean \\
\hline \multicolumn{7}{|l|}{$\begin{array}{c}\text { Before } \\
\text { feeding }\end{array}$} \\
\hline $\begin{array}{l}\text { Serum } \\
\text { A-E Sol. } \\
\text { A-E/S* }\end{array}$ & $\begin{array}{l}61 \\
1.4 \\
0.02\end{array}$ & $\begin{array}{c}49-91 \\
0.3-2.8 \\
0.01-0.04\end{array}$ & $\begin{array}{l} \pm 0.08 \\
\pm 0.01\end{array}$ & $\begin{array}{l}94 \\
5.5 \\
0.07\end{array}$ & $\begin{array}{c}66-190 \\
4.1-6.3 \\
0.03-0.09\end{array}$ & $\begin{array}{l} \pm 0.3 \\
\pm 0.01\end{array}$ \\
\hline \multicolumn{7}{|l|}{ 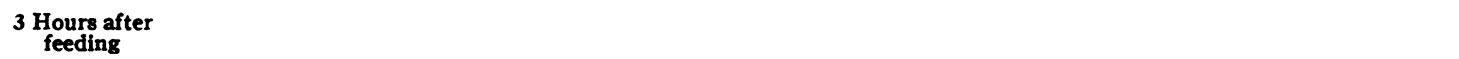 } \\
\hline $\begin{array}{l}\text { Serum } \\
\text { A-E Sol. } \\
\text { A-E/S }\end{array}$ & $\begin{array}{l}60 \\
4.82 \\
0.08\end{array}$ & $\begin{array}{c}45-68 \\
3.3-9.6 \\
0.06-0.15\end{array}$ & $\begin{array}{l} \pm 0.65 \\
\pm 0.01\end{array}$ & $\begin{array}{l}71 \\
5.9 \\
0.05\end{array}$ & $\begin{array}{c}60-83 \\
4.6-6.8 \\
0.07-0.10\end{array}$ & $\begin{array}{l} \pm 0.3 \\
\pm 0.01\end{array}$ \\
\hline \multicolumn{7}{|l|}{ 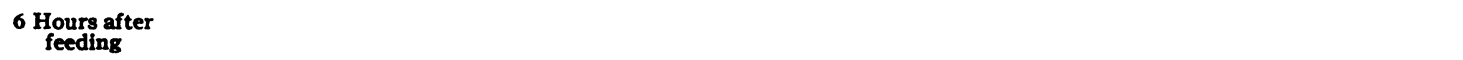 } \\
\hline $\begin{array}{l}\text { Serum } \\
\text { A-E Sol. } \\
\text { A-E/S }\end{array}$ & $\begin{array}{l}71 \\
5.8 \\
0.08\end{array}$ & $\begin{array}{c}59-88 \\
1.8-23.4 \\
0.02-0.31\end{array}$ & $\begin{array}{l} \pm 1.68 \\
\pm 0.01\end{array}$ & $\begin{array}{l}82 \\
5.8 \\
0.07\end{array}$ & $\begin{array}{c}66-98 \\
3.2-7.7 \\
0.03-0.09\end{array}$ & $\begin{array}{l} \pm 0.6 \\
\pm 0.01\end{array}$ \\
\hline \multicolumn{7}{|l|}{$\begin{array}{l}12 \text { Hours after } \\
\text { feeding }\end{array}$} \\
\hline $\begin{array}{l}\text { Serum } \\
\text { A-E Sol. } \\
\text { A-E/S }\end{array}$ & $\begin{array}{l}74 \\
12.2 \\
0.17\end{array}$ & $\begin{array}{c}49-91 \\
5.5-27.0 \\
0.07-0.36\end{array}$ & $\begin{array}{l} \pm 5.7 \\
\pm 0.01\end{array}$ & $\begin{array}{l}79 \\
7.3 \\
0.09\end{array}$ & $\begin{array}{c}59-95 \\
4.8-14.0 \\
0.06-0.16\end{array}$ & $\begin{array}{l} \pm 1.1 \\
\pm 0.01\end{array}$ \\
\hline \multicolumn{7}{|l|}{$\begin{array}{l}24 \text { Hours after } \\
\text { feeding }\end{array}$} \\
\hline $\begin{array}{l}\text { Serum } \\
\text { A-E Sol. } \\
\text { A-E/S }\end{array}$ & & & & $\begin{array}{c}133 \\
11.4 \\
0.08\end{array}$ & $\begin{array}{r}81-165 \\
3.8-28.4 \\
0.03-0.18\end{array}$ & $\begin{array}{l} \pm 3.5 \\
\pm 0.01\end{array}$ \\
\hline
\end{tabular}

* A-E/S: Ratio of cholesterol in solvent/cholesterol in original serum. 
TABLE II

The cholesterol extraction of the intestinal lymph of the rat

\begin{tabular}{|c|c|c|c|c|c|c|}
\hline \multirow{3}{*}{$\begin{array}{l}\text { No. of } \\
\text { rats }\end{array}$} & \multirow{3}{*}{$\underset{(g m .)}{\text { Av. wt. }}$} & & \multicolumn{4}{|c|}{ Lymph (24-Hour collection) } \\
\hline & & & \multirow{2}{*}{$\underset{(m l .)}{\text { Volume }}$} & \multicolumn{3}{|c|}{ Cholesterol (mg./100 ml.) } \\
\hline & & & & Lymph & A-E Sol. & A-E/L* \\
\hline \multicolumn{7}{|c|}{ (Rats given $3.0 \mathrm{ml}$. of $\mathrm{H}_{2} \mathrm{O}$ ) } \\
\hline 6 & 294 & $\begin{array}{l}\text { Range } \\
\text { S.E. mean }\end{array}$ & $\begin{array}{c}25.0 \\
(20.0-29.0)\end{array}$ & $\begin{array}{c}43.0 \\
(26.0-57.0) \\
\pm 4.3\end{array}$ & $\begin{array}{c}6.4 \\
(1.0-11.2) \\
\pm 1.6\end{array}$ & $\begin{array}{l}0.14 \\
(0.04-0.21) \\
\pm 0.03\end{array}$ \\
\hline \multicolumn{7}{|c|}{ (Rats given $3.0 \mathrm{ml}$. of olive oil) } \\
\hline 18 & 302 & $\begin{array}{l}\text { Range } \\
\text { S.E. mean }\end{array}$ & $\begin{array}{c}37.0 \\
(18.0-59.0)\end{array}$ & $\begin{array}{c}37.0 \\
(17.4-54.0) \\
\pm 1.1\end{array}$ & $\begin{array}{c}10.2 \\
(0.8-23.4) \\
\pm 1.7\end{array}$ & $\begin{array}{c}0.263 \\
(0.04-0.65) \\
\pm 0.04\end{array}$ \\
\hline \multicolumn{7}{|c|}{ (Rats given $3.0 \mathrm{ml}$. of olive oil $+100 \mathrm{mg}$. of cholesterol) } \\
\hline 25 & 316 & $\begin{array}{l}\text { Range } \\
\text { S.E. mean }\end{array}$ & $\begin{array}{c}37.0 \\
(15.0-83.0)\end{array}$ & $\begin{array}{c}92.0 \\
(44.0-202.0) \\
\pm 6.1\end{array}$ & $\begin{array}{c}41.7 \\
(4.5-124.0) \\
\pm 6.3\end{array}$ & $\begin{array}{c}0.403 \\
(0.10-0.83) \\
\pm 0.04\end{array}$ \\
\hline
\end{tabular}

* A-E/L: Ratio of cholesterol in solvent/cholesterol in original lymph.

cholesterol (16.5 per cent) was extracted from the turbid, chylomicronemic sera obtained from the rats 12 hours after the ingestion of the cholesterol. As Table IV shows, the amount of cholesterol capable of being extracted from the sera of unfed control rats does not change after repeated bleedings, and these sera also never exhibited turbidity or chylomicronemia. These results indicate that although the total cholesterol concentration of the sera of rats does not change markedly after cholesterol ingestion, the physicochemical status of the cholesterol is markedly altered. This is shown by the extraction of a portion of the serum cholesterol at 12 hours following the intake of cholesterol almost nine times as great as may be extracted by alcohol-ether extraction before feeding. This alteration in extraction appeared to proceed pari passu with the degree of lipemia, as judged by visual estimation of the turbidity of serum samples.

The results obtained from the extraction of sera of cholesterol fed rabbits were somewhat similar except the increase in extraction was delayed. Thus (see Table I), no significant increase occurred either in the total cholesterol concentration or in the extractable portion either at 3 , 6 or 12 hours after the oral ingestion of the cholesterol. Similarly, no discernible increase in turbidity was observed nor were chylomicra observed. At the end of 24 hours, the sera were moderately turbid and chylomicronemic and con- tained considerably more cholesterol (133 mg. per $100 \mathrm{ml}$.). The amount of cholesterol extracted from these sera was about double that able to be extracted prior to cholesterol feeding. The percentage of extraction, however, did not increase appreciably because of the actual increase in cholesterol concentration of the sera.

\section{B. The cholesterol extraction of intestinal lymph of the rat}

Unchanged intestinal lymph. The intestinal lymph of the six rats given only $\mathrm{H}_{2} \mathrm{O}$ contained considerable cholesterol (43 mg. per $100 \mathrm{ml}$.), and a moderate amount of it could be extracted with the A-E solution, the latter's concentration of cholesterol being $6.4 \mathrm{mg}$. per $100 \mathrm{ml}$. or approximately 14 per cent of the initial lymph concentration (see Table II). The lymph itself was moderately turbid and exhibited a number of chylomicra.

The lymph samples of the 18 rats given $3 \mathrm{ml}$. of olive oil were very turbid and contained myriads of chylomicra. The average cholesterol concentration of these lymphs was $37 \mathrm{mg}$. per $100 \mathrm{ml}$. (see Table II) and a considerable portion was capable of extraction. Thus the A-E solution (see Table II) contained $10.2 \mathrm{mg}$. per $100 \mathrm{ml}$. or about 26 per cent of the initial lymph cholesterol concentration.

The lymph samples of the 25 rats given $100 \mathrm{mg}$. of cholesterol in $3 \mathrm{ml}$. of olive oil were similar to 
the above samples in the intensity of their turbidity and chylomicron content. The average cholesterol content of this lymph was $92 \mathrm{mg}$. per $100 \mathrm{ml}$. and compared to the preceding lymphs, a greater portion of its cholesterol was capable of extraction. The A-E solution (see Table II) contained 41.7 $\mathrm{mg}$. per $100 \mathrm{ml}$. or approximately 40 per cent of the initial lymph concentration.

Ultracentrifuged portions of intestinal lymph. The five lymph samples which were collected from rats given $100 \mathrm{mg}$. of cholesterol in $3 \mathrm{ml}$. of olive oil separated on ultracentrifugation into two distinct phases. The upper phase which consisted of a dense white cake having a volume of less than $1.0 \mathrm{ml}$. was removed and suspended by stirring in $5 \mathrm{ml}$. of $\mathrm{H}_{2} \mathrm{O}$. The lower phase was only slightly turbid and contained only a few chylomicra. It resembled the intact lymph obtained from the water-fed rats.

The cholesterol concentration of the A-E solution after the latter's contact with the original intact lymph averaged $46 \mathrm{mg}$. per $100 \mathrm{ml}$. (see Table III) or about 38 per cent of the initial lymph concentration.

When the top phase of the ultracentrifuged lymph samples was redissolved and then exposed to the A-E solution, the latter obtained an average cholesterol concentration of $55 \mathrm{mg}$. per 100 $\mathrm{ml}$. or 64 per cent of the cholesterol concentration of the initial concentration of the redissolved top phase. On the other hand, similar exposure of the lower phase of the ultracentrifuged lymph to A-E solution resulted in an average cholesterol content of only $8.0 \mathrm{mg}$. per $100 \mathrm{ml}$. in the latter solution or about 15 per cent of the initial con- centration in the lower phase. Clearly then, the cholesterol content of the chylomicra was far more easily extracted than the cholesterol predominantly in solution in the lower phase of the ultracentrifuged lymph.

\section{The cholesterol extraction of rat hypercho- lesteremic sera}

Two entirely different types of hypercholesteremic serum were studied. The first hypercholesteremic serum was obtained from rats subjected to bile obstruction for 24 hours. This serum was perfectly clear, exhibited no chylomicra but contained about 2 to 3 times more total lipid than the serum of the normal fasted rat. Its lipoproteins, however, exhibited a relatively low flotation rate (9). The second type of hypercholesteremic serum, obtained from rats injected with Triton six and 24 hours previously, was intensely turbid and contained far more total lipid (approximately twice as much as the serum from rats with ligated bile ducts). The turbidity was due to particles which, although not visible even at 1000 diameters magnification, could be separated in great part by centrifugation at 20,000 r.p.m. (r.c.f. 25,000 to 40,000). Such particles ostensibly are rich in lipids other than cholesterol which probably accounts for the marked alteration in the lipoprotein spectrum occurring after Triton administration (10).

As Table IV indicates, layering with A-E solution resulted in significantly increased extraction of cholesterol from the sera of rats obtained six hours after biliary obstruction and also resulted in a considerable increase in extraction from the

TABLE III

The cholesterol extraction of intestinal lymph before and after ultracentrifugation

\begin{tabular}{|c|c|c|c|c|c|c|c|c|c|c|c|}
\hline \multirow[b]{5}{*}{ Rat } & \multirow[b]{5}{*}{$\begin{array}{c}\text { Weight } \\
(\mathrm{gm} .)\end{array}$} & \multicolumn{10}{|c|}{ Intestinal lymph collection (24 hours) } \\
\hline & & \multirow{3}{*}{\multicolumn{4}{|c|}{ Unchanged lymph }} & \multicolumn{6}{|c|}{ Ultracentrifuged lymph } \\
\hline & & & & & & \multicolumn{6}{|c|}{ Cholesterol (mg./100 ml.) } \\
\hline & & & & & & \multicolumn{3}{|c|}{ Upper layer* } & \multicolumn{3}{|c|}{ Lower layer } \\
\hline & & $\begin{array}{l}\text { Vol. } \\
(m l .)\end{array}$ & Lymph & A-E Sol. & A-E/L & $\begin{array}{l}\text { Intact } \\
\text { layer }\end{array}$ & A-E & A-E/I.L. & $\begin{array}{l}\text { Intact } \\
\text { layer }\end{array}$ & A-E & A-E/I.L. \\
\hline $\begin{array}{l}18 \\
19 \\
21 \\
22\end{array}$ & $\begin{array}{l}290 \\
280 \\
254 \\
276\end{array}$ & $\begin{array}{l}28 \\
26 \\
16 \\
26\end{array}$ & $\begin{array}{r}120 \\
94 \\
161 \\
112\end{array}$ & $\begin{array}{l}44 \\
30 \\
55 \\
55\end{array}$ & $\begin{array}{l}0.37 \\
0.32 \\
0.34 \\
0.49\end{array}$ & $\begin{array}{r}73 \\
61 \\
125 \\
85\end{array}$ & $\begin{array}{l}49 \\
41 \\
79 \\
51\end{array}$ & $\begin{array}{l}0.67 \\
0.67 \\
0.63 \\
0.60\end{array}$ & $\begin{array}{l}38 \\
37 \\
98 \\
31\end{array}$ & $\begin{array}{r}5.5 \\
7.5 \\
14.0 \\
5.0\end{array}$ & $\begin{array}{l}0.15 \\
0.22 \\
0.14 \\
0.16\end{array}$ \\
\hline Av. & 275 & 24 & 122 & 46 & 0.38 & 86 & 55 & 0.64 & 51 & 8.0 & 0.17 \\
\hline
\end{tabular}

* Top layer obtained from ultracentrifugation was resuspended in $5.0 \mathrm{ml}$. of physiological saline solution. 
TABLE IV

The cholesterol extraction of serum of hypercholesteremic rats

\begin{tabular}{|c|c|c|c|c|c|c|c|c|c|}
\hline & \multicolumn{3}{|c|}{ Control rats (6) } & \multicolumn{3}{|c|}{ Bile obstructed rats (11) } & \multicolumn{3}{|c|}{ Rats injected with Triton (10) } \\
\hline & Av. & Range & S.E. mean & Av. & Range & S.E. mean & Av. & Range & S.E. mean \\
\hline \begin{tabular}{l}
\multicolumn{1}{c}{ Before } \\
experiment \\
Serum \\
A-E Sol. \\
A-E/S
\end{tabular} & $\begin{array}{l}52 \\
1.1 \\
0.02\end{array}$ & $\begin{array}{c}44-56 \\
0.5-1.8 \\
0.01-0.03\end{array}$ & $\begin{array}{l} \pm 0.3 \\
\pm 0.01\end{array}$ & $\begin{array}{l}56 \\
0.98 \\
0.02\end{array}$ & $\begin{array}{c}50-64 \\
0.6-1.4 \\
0.01-0.03\end{array}$ & $\begin{array}{l} \pm 0.08 \\
\pm 0.005\end{array}$ & $\begin{array}{l}57 \\
1.7 \\
0.03\end{array}$ & $\begin{array}{c}49-71 \\
0.6-2.7 \\
0.01-0.04\end{array}$ & $\begin{array}{l} \pm 0.26 \\
\pm 0.01\end{array}$ \\
\hline \multicolumn{10}{|l|}{$\begin{array}{l}\text { Six hrs. after } \\
\text { experiment } \\
\text { begun }\end{array}$} \\
\hline $\begin{array}{l}\text { Serum } \\
\text { A-E Sol. } \\
\text { A-E/S }\end{array}$ & $\begin{array}{l}48 \\
1.6 \\
0.04\end{array}$ & $\begin{array}{c}42-50 \\
1.5-1.7 \\
0.03-0.04\end{array}$ & $\begin{array}{l} \pm 0.03 \\
\pm 0.02\end{array}$ & $\begin{array}{l}63 \\
2.5 \\
0.04\end{array}$ & $\begin{array}{c}54-70 \\
0.8-4.4 \\
0.02-0.07\end{array}$ & $\begin{array}{l} \pm 0.04 \\
\pm 0.06\end{array}$ & $\begin{array}{c}169 \\
63.0 \\
0.37\end{array}$ & $\begin{array}{c}146-207 \\
28-92 \\
0.18-0.48\end{array}$ & $\begin{array}{l} \pm 6.1 \\
\pm 0.03\end{array}$ \\
\hline \multicolumn{10}{|l|}{$\begin{array}{l}24 \text { hrs. after } \\
\text { experiment } \\
\text { begun }\end{array}$} \\
\hline $\begin{array}{l}\text { Serum } \\
\text { A-E Sol. } \\
\text { A-E/S }\end{array}$ & $\begin{array}{l}55 \\
1.3 \\
0.023\end{array}$ & $\begin{array}{c}52-58 \\
1.2-1.5 \\
0.02-0.03\end{array}$ & $\begin{array}{l} \pm 0.07 \\
\pm 0.03\end{array}$ & $\begin{array}{c}131 \\
12.1 \\
0.10\end{array}$ & $\begin{array}{c}95-171 \\
2.8-32.0 \\
0.03-0.29\end{array}$ & $\begin{array}{l} \pm 2.7 \\
\pm 0.02\end{array}$ & $\begin{array}{l}341 \\
145 \\
0.43\end{array}$ & $\begin{array}{l}299-422 \\
112-174 \\
0.31-0.52\end{array}$ & $\begin{array}{l} \pm 5.3 \\
\pm 0.03\end{array}$ \\
\hline
\end{tabular}

sera obtained after 24 hours of obstruction. Thus the average cholesterol content extracted from the 24-hour sera was $12.1 \mathrm{mg}$. per $100 \mathrm{ml}$. and the extraction ratio rose from 2 to 10 per cent.

The sera obtained from Triton-injected rats contained far more extractable cholesterol both at six and 24 hours after injection. The A-E solution contained $63 \mathrm{mg}$. at six and $145 \mathrm{mg}$. of cholesterol per $100 \mathrm{ml}$. at 24 hours, respectively, after injection of Triton (Table IV). Undoubtedly this greater degree of extraction compared with that of the previous type of hypercholesteremic serum was due in part to the greater content of cholesterol in the serum of the Triton-injected rats. However, the extraction ratio similarly increased markedly being 37 and 43 per cent at six and 24 hours, respectively.

\section{DISCUSSION}

In the present study, the cholesterol of intestinal lymph of the unfed rat was found to be considerably more extractable than its counterpart in serum, possibly due in part to the fact that some of the cholesterol in lymph (perhaps that portion reabsorbed from that previously excreted into the intestine) (11) travels in a lipid particle (1). Also, there is considerably less protein available in intestinal lymph for lipoprotein bondage than is the case with serum (12). After fat or cholesterol feeding, the amount of cholesterol extractable from intestinal lymph increased markedly and this net increment was observed to be present in the chylomicra (i.e., in the upper layer of the ultracentrifuged lymph). The extraction of the lower layer of the ultracentrifuged lymph of the cholesterol-fat-fed rat however (see and compare Tables II and III) yielded about the same ratio of extracted to total cholesterol as that of the intact lymph of the fasted rat. In other words, cholesterol enmeshed in lipid appeared to be more readily extractable than cholesterol attached to protein as a serum soluble lipoprotein.

The rise observed in the cholesterol extraction ratio of hypercholesteremic and hyperlipemic sera is a phenomenon which confirms the observations of Forbes, Dillard, Porter, and Petterson (4). They noted that a greater proportion of the cholesterol of sera of nephrotic individuals was extracted by chloroform treatment than was extracted from the cholesterol present in sera of normal individuals. In both of the experimentally induced hypercholesteremic states of this study and also in the nephrotic state (4), an excess of lipid is also present in the serum. The conclusion then seems warranted that the cholesterol present in a hyperlipemic serum is more easily extractable than the cholesterol present in a normolipemic serum.

Although the present experiments suggest that cholesterol can be extracted to some extent even when not existing in visible chylomicron form, as was found when the chylomicron free serum of rats with biliary obstruction was treated with the A-E solvent, nevertheless, the cholesterol of those 
lymph and serum samples exhibiting the greatest concentration of lipid aggregates was found to be most readily extracted. Since the presence of lipid aggregates necessarily implies a state of supersaturation of the plasma with regard to at least one of the lipid components, it is possible that two causes may contribute independently to the extractability of cholesterol (13). In other words, the increased amount of total lipid may 1) remove some of the cholesterol from soluble lipoprotein form into aggregate form, and 2) alter some of the remaining soluble lipoprotein-cholesterol so that it is more readily extractable.

In the absence, however, of an endogenous form of hypercholesteremia or hyperlipemia, changes in the per cent of serum cholesterol which may be extracted might only be expected following changes in the lipid concentration of plasma. The present experiments involving both the rat and rabbit fed cholesterol and fat suggest that such changes in cholesterol extractability may occur during the post alimentary period.

\section{SUMMARY}

Extraction with an alcohol-ether solution of various types of sera and lymph samples obtained from rats permitted a partial extraction of their cholesterol content. The degree of extractability of cholesterol of any sample appeared to be a function dependent in part at least upon the increase in serum lipid.

\section{ACKNOWLEDGMENT}

The authors wish to express their appreciation for the technical assistance of Barbara Gunning and Gonzalo Monarque.

\section{REFERENCES}

1. Byers, S. O., and Friedman, M., Observations concerning the production and excretion of cholesterol in mammals. XIII. Role of chylomicra in trans- port of cholesterol and lipid. Am. J. Physiol., 1954, 179, 79.

2. Friedman, M., and Byers, S. O., Observations concerning the production and excretion of cholesterol in mammals. XIV. The relationship of the hepatic reticulo-endothelial cell (Kupffer cell) to endogenously produced cholesterol. Circulation, 1954, 10, 491.

3. Macheboeuf, A., and Sandor, G., Etude de l'Extraction des Lipides du Sérum Sanguin par l'Ether en Présence d'Alcool. Compt rend. Acad. d. sc., 1932, 194, 1102.

4. Forbes, J. C., Dillard, G. H. L., Porter, W. B., and Petterson, O., Fractionation of serum cholesterol. Proc. Soc. Exper. Biol. \& Med., 1948, 68, 240.

5. Duff, G. L., and Payne, T. P. B., The effect of alloxan diabetes on experimental cholesterol atherosclerosis in the rabbit. III. The mechanism of the inhibition of experimental cholesterol atherosclerosis in alloxan-diabetic rabbits. J. Exper. Med., 1950, 92, 299.

6. Saifer, A., and Kammerer, O. F., Photometric determination of total cholesterol in plasma or serum by a modified Liebermann-Burchard reaction. J. Biol. Chem., 1946, 164, 657.

7. Bragdon, J. H., Colorimetric determination of blood lipides. J. Biol. Chem., 1951, 190, 513.

8. Friedman, M., and Byers, S. O., Cholic acid: An adequate stimulus for hypercholesteremia in the normal fasting rat. Proc. Soc. Exper. Biol. \& Med., 1951, 78, 528.

9. Byers, S. O., Friedman, M., Biggs, M. W., and Gunning, B., Observations concerning the production and excretion of cholesterol in mammals. IX. The mechanism of the hypercholesteremic effect of cholic acid. J. Exper. Med., 1953, 97, 511.

10. Friedman, M., and Byers, S. O., The mechanism responsible for the hypercholesteremia induced by Triton WR-1339. J. Exper. Med., 1953, 97, 117.

11. Beumer, H., and Hepner, F., Uber die Ausscheidungswege des Cholesterins. Ztschr. f. d. ges. exper. Med., 1929, 64, 789.

12. Albrink, M. J., Glenn, W. W. L., Peters, J. P., and Man, E. B., The transport of lipids in chyle. J. Clin. Invest., 1955, 34, 1467.

13. Albrink, M. J., Man, E. B., and Peters, J. P., The relation of neutral fat to lactescence of serum. J. Clin. Invest., 1955, 34, 147. 